\title{
Second-Line Chemotherapy for Platinum- and Taxane-Resistant Epithelial Ovarian Cancer: Pegylated Liposomal Doxorubicin (PLD), Irinotecan, and Combination Therapies at Lower Doses
}

\author{
Toru Sugiyama \\ Obstetrics and Gynecology, Iwate Medical University \\ School of Medicine, Morioka City \\ Japan
}

\section{Introduction}

Epithelial ovarian cancer is sensitive to chemotherapy and approximately $75 \%$ of patients achieve complete clinical remission after the initial treatment. However, most develop a recurrence which results in death after a chronic course. Therefore, most patients are candidates for second-line chemotherapy, including approximately $20 \%$ among of these patients with platinum- and taxane-resistant disease. Patients with platinum-and taxaneresistant disease have poor outcomes, and most would like to prolong their survival with relieved symptoms and the best possible quality of life (QOL). The effects of several drugs which are being used for these purposes are similar, but it is usually difficult to relieve recurrent disease with one drug. Monotherapy has been generally chosen for having the most favorable toxicity profile in patients with platinum- and taxane-resistant disease. However, it is not clear whether this strategy is optimal with the various novel anticancer drugs and targeted agents under development. In this article, pegylated liposomal doxorubicin (PLD), which is used worldwide, and irinotecan, the predominant agent in Japan for the treatment of platinum- and taxane-resistant ovarian cancer, are evaluated for their effects and toxicity in monotherapy and in combination at lower doses with other drugs.

\section{Objectives}

Platinum- and taxane-resistant epithelial ovarian cancer is not curable; therefore, patients give fully informed consent and are treated to maintain their QOL. The initial treatment aims to cure cancer while the second-line chemotherapy seeks palliation as the primary goal. To be specific, the aim is to balance toxicity and the beneficial effects, and considering the toxicities after the initial treatment and patient's desires, more convenient and less toxic agents should be chosen. Second-line chemotherapy is intended to prevent deterioration of cancer lesions and to relieve symptoms. 


\section{Principle for choosing therapy}

In the treatment of recurrent ovarian cancer, the issues to consider are the treatment-free interval (TFI), toxicity continuously observed from the initial treatment, recurrent tumor diameter and increased CA125. The TFI is the most important for selecting regimens, and the longer the TFI, the higher the response rate (Figure 1).1,2) In selecting regimens, when the TFI is 6 months or longer, the tumor is considered to be sensitive to chemotherapy. In contrast, when the TFI is less than 6 months, the tumor is considered to be resistant to chemotherapy. For patients with a platinum- and taxane- resistant disease, a drug without cross-resistance to paclitaxel and carboplatin must be selected. On the other hand, recommended therapies for tumors sensitive to drugs, based on the results of randomized controlled trials and meta-analyses, are carboplatin- combination therapy with or without a targeted agent. However, 6-12 months of TFI is considered to be a gray zone (platinumresistant factor remains; partially sensitive) and more careful consideration should be needed in choosing regimens.

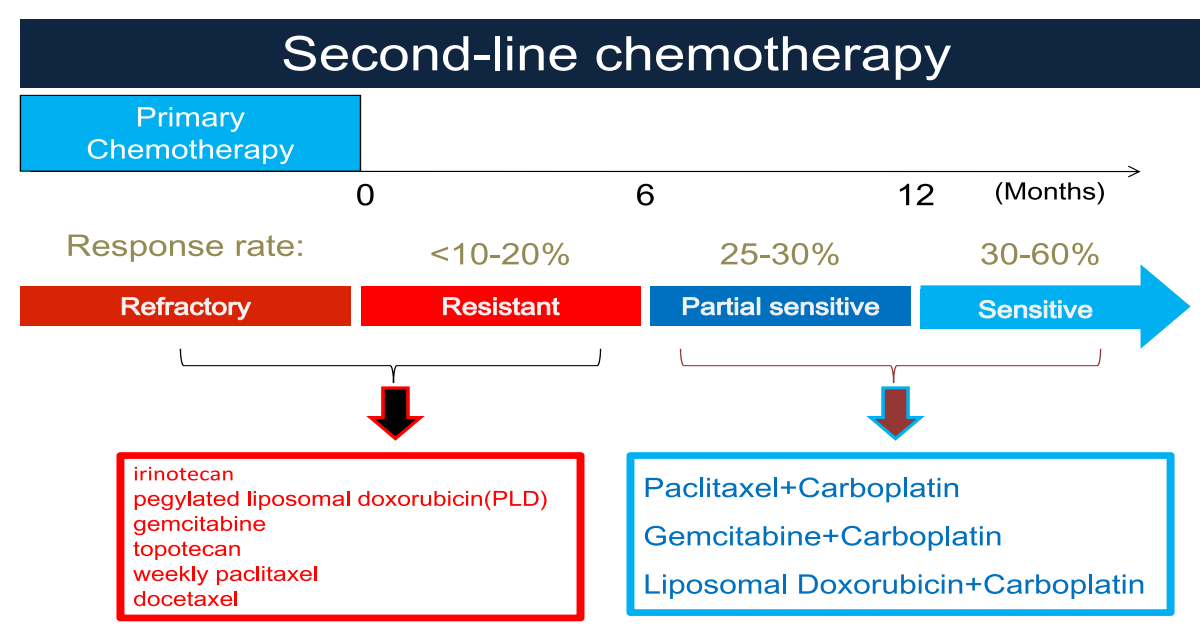

Fig. 1. Principle for choosing therapy.

Pegylated liposomal doxorubicin (PLD), topotecan, and weekly paclitaxel are the drugs approved by the Food and Drug Administration (FDA), and gemcitabine (GEM), oral etoposide, and docetaxel can also be used. In Japan, weekly irinotecan is frequently used. The effects of drugs on patients with platinum- and taxane-resistant disease are similar and no drug can complete the treatment in most patients. Based on the performance status (PS) and toxicity persisting from the initial treatment and the bone-marrow function of an individual patient, drugs to be administered should be presented to the patient. PLD is safer for heavily pretreated patients than topotecan and GEM due to mild bone-marrow toxicity, however, nonhematotoxity such as hand-foot syndrome (HFS), stomatitis and mucositis frequently develop, patient's desire is considered, finally, the drugs are selected. 3) However, it is usually difficult to completely relieve cancer with one drug with high efficacy and low toxicity, and the drugs are therefore changed as required while assessing the effect and toxicity. 


\section{Effects and toxicities}

\subsection{Effects}

The response rate of anticancer drugs in platinum-resistant ovarian cancer ranges from $12 \%$ to $32 \%$, and the survival (median) is around $8-10$ months. The effect of anticancer drugs is generally evaluated by the change in tumor diameter; i.e., if the tumor diameter increases, outcomes are judged to be progressive disease (PD) and the treatment is discontinued or changed, and if the tumor diameter decreases, the treatment is evaluated to be effective and continued if no toxicity-related problem occurs. However, it was shown in several studies that such direct evaluation results of tumor diameter do not always correlate with survival time. We investigated the relationship between the drug-induced change in tumor diameter and survival, albeit in a small-size population, and showed that there was no difference in the survival time between the patients with complete response (CR) or partial response (PR) and those with stable disease (SD), and that only patients with PD showed particularly poor outcomes (the IGCS Symposium, Edinburgh, 2004). Cesano et al. showed similar results. 4) Rose et al. recently analyzed outcomes of patients with platinum-resistant ovarian ovarian cancer who were enrolled in 11 GOG phase II clinical trials (1996-2004) and compared the survival time between the CR/PR, SD and PD groups (Figure 2). 5) The results showed no difference between the CR/PR and the SD groups while the overall survival (OS) in the PD group was significantly poorer than that in the $C R / P R / S D$ group $(p<0.001)$. Given these corroborating results, it is important to evaluate the effect of treatment by the total percent of responders and patients with SD who have no increase in tumor size (disease control rate) in treatments of patients with platinum-resistant disease. This percent is expressed as the clinical benefit. Consequently, it is considered that patients with platinum- and taxaneresistant ovarian cancer who have tumors evaluable as $\mathrm{SD}$ as well as CR/PR are given effective treatment when patients have no toxicity problems and can maintain their QOL.

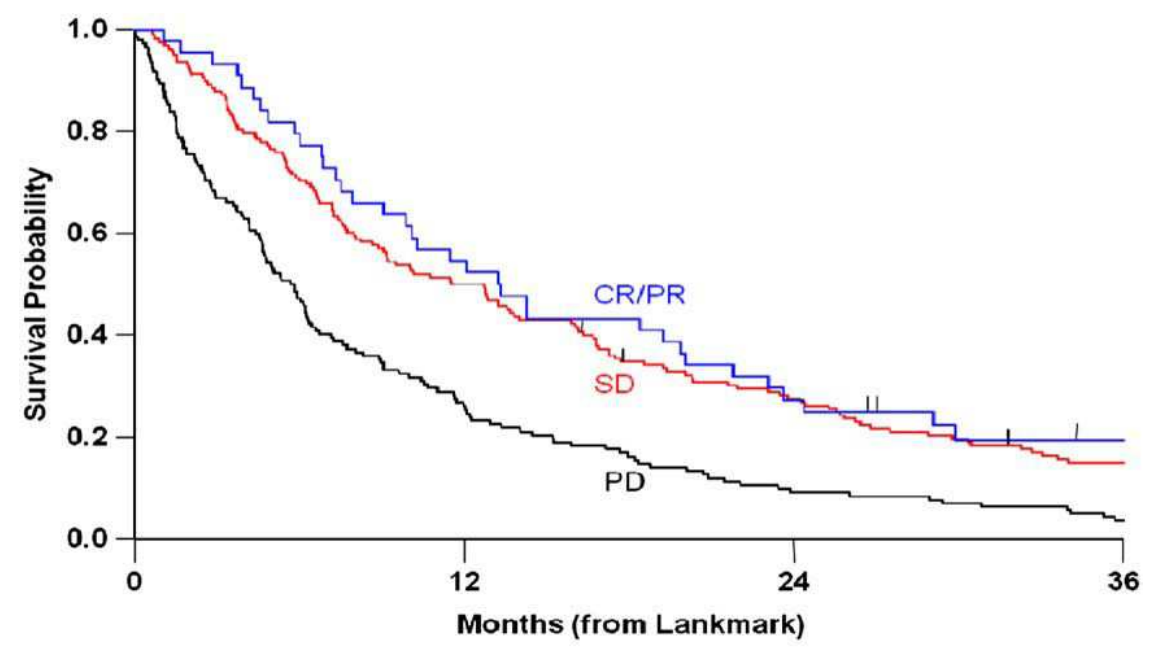

$\mathrm{CR} / \mathrm{PR}=$ Complete and Partial Response, $\mathrm{SD}=$ Stable Disease, $\mathrm{PD}=$ Progresive Disease

Rose PG, et al. Gynecol Oncol. 2010;17:324-329

Fig. 2. Survival by tumor response status (landmark analysis) 


\subsection{Toxicity}

The toxicity depends on agents but generally tends to increase with the frequency of chemotherapy. Therefore, in the treatment of platinum- and taxane- resistant ovarian cancer, much attention should be given to the occurrence of toxicities. Topotecan, GEM, docetaxel are highly hemotoxic, and patients using PLD, irinotecan, or weekly paclitaxel should be monitored for non-hemotoxic events that reduce the QOL. There is concern about HFS occurring in treatment with PLD, diarrhea with irinotecan, and peripheral neuropathy and arthralgia during weekly paclitaxel therapy. When a patient is treated with irinotecan, diarrhea is frequently induced, therefore, informed consent for determination of UGT1A1 polymorphism should be obtained from the patient and the assay is carried out as needed. 6,7 )

\section{Pgylated liposomal doxorubicin (PLD)}

PLD was approved in 1999 by the FDA and in 2000 by the European Medicines Evaluation Agency as treatment for chemorefractory and chemoresistant epithelial ovarian cancer and has been used as the first option for patients with chemorefractory and chemoresistant epithelial ovarian cancer over the world.

\subsection{Efficacy}

The results of phase II/III studies of PLD showed response rates to platinum-resistant disease ranging from $8.7 \%$ to $31.4 \%$, SD rates from $18.2 \%$ to $51.3 \%$ and a high clinical benefit around $60 \%$, and no difference in the efficacy between 50 and $40 \mathrm{mg} / \mathrm{m}^{2}$ of PLD. A phase II study has recently been completed in Japan and the response rate for recurrent platinumresistant ovarian cancer was $21.0 \%$, the SD rate was $40.3 \%$ and the clinical benefit was $61.3 \%$, which was similar to those in the studies in Europe and the United States. ${ }^{8-15)}$

\subsection{Safety}

The data in Europe and the United States show that PLD is accompanied by a low incidence and low severity of hematotoxicities such as neutropenia. The incidence of neutropenia of grade $3 / 4$ ranges from $10 \%$ to $20 \%$, and granulocyte colony stimulating factor (G-CSF) drugs are seldom needed. The incidence of thrombopenia is lower. On the other hand, PLD is accompanied by high incidences of subjective non-hematotoxities including HFS and stomatitis at FDA-approved doses and schedules. HFS and stomatitis developed in approximately $40 \%$ of patients; however, HFS of grade 2 or higher were found in $19.8 \%$ to $31.5 \%$ of patients treated with PLD at a dose of $50 \mathrm{mg} / \mathrm{m}^{2}$ and $2.8 \%$ to $15.5 \%$ (less than half as frequently) at doses of $40 \mathrm{mg} / \mathrm{m}^{2}$ and less. Stomatitis of grade 2 or higher developed in $14 \%$ to $38 \%$ or more of patients treated with PLD at a dose of $50 \mathrm{mg} / \mathrm{m}^{2}$ and in $8.0 \%$ of those treated with $\left.40 \mathrm{mg} / \mathrm{m}^{2} .{ }^{8-15}\right)$ We showed the efficacy of cooling the wrists and ankles during infusion to prevent HFS (ESMO, Milan, 2010). We are currently conducting a clinical trial of stomatitis prevention.

Based on the review of previous studies, no difference in the efficacy between 50 and 40 $\mathrm{mg} / \mathrm{m}^{2}$ of PLD, therefore, a dose of $40 \mathrm{mg} / \mathrm{m}^{2}$ is preferable for patients with platinumresistant disease to reduce adverse events. To scientifically confirm the dosage, the Japanese Gynecologic Oncology Group (JGOG) has started a randomized comparative study of 50 and $40 \mathrm{mg} / \mathrm{m}^{2}$ of PLD in patients with platinum-and taxane- resistant ovarian cancer (TFI < 6 months). 


\subsection{Japanese-specific toxicity}

The incidences and severity of PLD-induced toxicity in the Japanese population are different from those in European and the United States populations. In a Phase II trial in Japan, the incidence of HFS was 78\% (Grade 2 or more: $51 \%$ ) and that of neutropenia of grade 3 or more was $68 \%$, suggesting the necessity of toxicity monitoring and treatment. ${ }^{16)}$

\subsection{Comparison with other drugs in Phase III trials}

- Topotecan: The response rate of topotecan was around $14 \%$ in patients with platinumand taxane-resistant ovarian cancer. In a phase III comparative study with paclitaxel, the response rate of topotecan was $13.3 \%$ in the platinum-resistant ovarian cancer group, better than paclitaxel's rate of $6.7 \% .{ }^{17}$ ) The time to progression in the topotecan group was significantly better than that in the paclitaxel group; consequently, topotecan was confirmed to have at least an equivalent effect to paclitaxel. In comparison with PLD, topotecan had a tendency of being more effective in terms of the progression free survival (PFS) and overall survival (OS) in the platinum-resistant ovarian cancer group; on the other hand, PLD was significantly more effective than topotecan in the platinumsensitive ovarian cancer group (Table 1). ${ }^{18)}$

\begin{tabular}{|c|c|c|c|c|}
\hline & \multicolumn{2}{|c|}{$\begin{array}{l}\text { Progression-free survival } \\
\text { (median, week) }\end{array}$} & \multicolumn{2}{|c|}{$\begin{array}{l}\text { Overall survival } \\
\text { (median, week) }\end{array}$} \\
\hline \multicolumn{5}{|l|}{ Gordon et al. (2001) } \\
\hline \multicolumn{5}{|l|}{ Platinum-sensitive } \\
\hline PLD $(n=109)$ & 28.9 & $P=0.037$ & 108 & $p=0.008$ \\
\hline topotecan $(n=111)$ & 23.3 & & 71 & \\
\hline \multicolumn{5}{|l|}{ Platinum-resistant } \\
\hline PLD $(n=130)$ & 9.1 & $p=0.733$ & 36 & $p=0.455$ \\
\hline topotecan $(n=124)$ & 13.6 & & 41 & \\
\hline \multicolumn{5}{|l|}{ Mutch et al. (2007) } \\
\hline \multicolumn{5}{|l|}{ Platinum-resistant } \\
\hline PLD $(n=96)$ & $3.1^{*}$ & $p=0.870$ & $13.5^{*}$ & $p=0.997$ \\
\hline gemcitabine $(n=99)$ & $3.6^{*}$ & & $12.7^{*}$ & \\
\hline \multicolumn{5}{|l|}{ Ferrandina et al. (2008)** } \\
\hline PLD $(n=75)$ & $16 * *$ & $p=0.411$ & $56 * *$ & $p=0.048$ \\
\hline gemcitabine $(n=77)$ & $20 * *$ & & $51 * *$ & \\
\hline $\begin{array}{l}* \text { months } \\
{ }^{* *} \text { Patients with treatment-free inte }\end{array}$ & $\mid<12$ & $\begin{array}{l}\text { Gordon AN et } \\
\text { Mutch DG et } \\
\text { Ferrandina G }\end{array}$ & $\begin{array}{l}t \text { al Gyneco } \\
\text { al J Clin On } \\
\text { et al J Clin }\end{array}$ & $\begin{array}{l}\text { Oncol 2004;95: 1-8 } \\
\text { ol 2007;25: 2811-2818 } \\
\text { Oncol 2008;26: 890-896 }\end{array}$ \\
\hline
\end{tabular}

Table 1. Survival of Randomized studies.

- Gemcitabine: The response rate at doses of $800-1,000 \mathrm{mg} / \mathrm{m}^{2} /$ week and the schedule of days 1,8 and 15 and one-week withdrawal was $13-14 \%$ in the platinum-resistant ovarian cancer group. Mutch et al. conducted a phase III comparative study with 
gemcitabine (GEM) that showed no significant differences in PFS and OS between PLD and GEM. 14) Ferrandina et al. reported no differences in PFS between PLD and GEM in relapsed patients with a treatment-free interval (TFI) of 12 months or less, but a significant efficacy in OS with PLD compared to GEM (Table 1). ${ }^{15)}$ From the results of the above phase III studies, PLD was considered to have similar efficacy as other novel drugs on platinum-resistant disease; however, it was more effective at improving the survival rate in patients with recurrent ovarian cancer, including platinum-sensitive cancer, than other drugs.

- Difference in toxicity: The results of phase III comparative studies with topotecan or GEM confirmed that HFS and stomatitis significantly developed in patients treated with $50 \mathrm{mg} / \mathrm{m}^{2}$ of PLD while the incidence of HFS was slightly higher in patients treated with $40 \mathrm{mg} / \mathrm{m}^{2}$ of PLD compared with those treated with GEM and no difference was found in the incidence of stomatitis between PLD and GEM. On the other hand, PLD induced hematotoxicity less than topotecan and gemcitabine. Although neutropenia of grade 3 or more developed in $10 \%$ to $20 \%$ of patients treated with $50 \mathrm{mg} / \mathrm{m}^{2}$ of PLD, febrile neutropenia was rarely found. The incidence of thrombocytopenia was further less. ${ }^{13-15)}$

\subsection{Combination with other drugs}

In multidrug therapy, toxicity is often increased by the combination of multiple drugs at doses recommended for monotherapy. In contrast to initial chemotherapy, which aims to cure cancer, second-line chemotherapy aims to combine drugs at lower doses, considering the toxicity based on the results of phase I clinical studies. In particular, drugs with nonhematotoxicity such as PLD should be used in accordance with the above consideration. ${ }^{3)}$ In fact, in phase II clinical trials, the incidence and severity of PLD-specific non-hematotoxicities (HFS, stomatitis) were reduced without loss of efficacy when PLD was administered at lower doses in combination with GEM, topotecan, vinorelbine, and oxaliplatin.

In vitro data suggested a potential synergistic interaction between PLD and GEM. 19) Combination chemotherapy of PLD and GEM achieved good response rates ranging from $22 \%$ to $33 \%$, however, the clinical benefit was between $28 \%$ and $61 \%$, which was similar to PLD monotherapy. ${ }^{20-23)}$ As for hematotoxicity, neutropenia of grade 3/4 was slightly higher and HFS of grade 2/3 was slightly less. The combination of PLD and GEM is an active and acceptably tolerated option in the treatment of patients with platinum-resistant ovarian cancer (Table 2). The combination at the dosages chosen seems suitable for this patient population. Synergism between PLD and topotecan was demonstrated in platinum-resistant disease. ${ }^{24)}$ A median total response rate of $28 \%$ and clinical benefit of $72 \%$ were demonstrated, with a median TTP of 30+weeks in the combination of PLD and topotecan for platinum-resistant disease (Table 3).25) These data compare favorably to the data of both the drugs administered as single agent. In comparison of two studies of combination chemotherapy of PLD and oxaliplatin, the response rates for platinum-resistant disease were $28.6 \%$ and $38.5 \%$ and the clinical benefit was $71.4 \%$ and $76.9 \%$, suggesting the higher efficacy compared with PLD monotherapy. 26,27) Furthermore, the response rates for platinum-sensitive disease were $66.7 \%$ and $81.5 \%$ and the clinical benefit was $82.8 \%$ and $100 \%$, showing the efficacy similar or more to other platinum combination chemotherapy (Table 3). The incidence of HFS was low and no marked increase in hematotoxicity was found, consequently, it was considered to be controllable. Consequently, PLD, with its low hematotoxicity but specific non-hematotoxicities, is recommended for use not as a monotherapy but in low-doses combinations for improved patient QOL. 
Second-Line Chemotherapy for Platinum- and Taxane-Resistant Epithelial Ovarian Cancer:

Pegylated Liposomal Doxorubicin (PLD), Irinotecan, and Combination Therapies at Lower Doses

\begin{tabular}{|c|c|c|c|c|c|c|c|}
\hline \multirow{2}{*}{$\begin{array}{c}\text { Author } \\
\text { (year) }\end{array}$} & \multirow{2}{*}{$\begin{array}{r}\text { No. of pts } \\
\text { with pl-resist. } \\
\end{array}$} & \multirow{2}{*}{$\begin{array}{c}\text { Dose/ } \\
\text { Schedule }\end{array}$} & \multirow[t]{2}{*}{ RR(\%) } & \multirow{2}{*}{$\begin{array}{c}\text { Clinical } \\
\text { benefit(\%) }\end{array}$} & \multirow{2}{*}{$\begin{array}{c}\text { Response } \\
\text { duration(wk) }\end{array}$} & \multicolumn{2}{|c|}{ Toxicity $(\%)$} \\
\hline & & & & & & G3/4neutro & PPE \\
\hline $\begin{array}{l}\operatorname{Agostino}^{1} \\
\text { (2003) }\end{array}$ & 38 & $\begin{aligned} & \text { P: } 30 \mathrm{mg} / \mathrm{m}^{2}(\mathrm{~d} 1) \\
& \text { G: } 1000 \mathrm{mg} / \mathrm{m}^{2}(\mathrm{~d} 1,8) \\
& \text { q3wk }\end{aligned}$ & 25.0 & 61.1 & 18.0 & 35.6 & 25.7 (G2/3) \\
\hline $\begin{array}{l}\text { Ferrandina }{ }^{2} \\
(2005) Q 3 w k\end{array}$ & $\begin{array}{ll}2 & 66 \\
k & \end{array}$ & $\begin{array}{l}\text { P: } 30 \mathrm{mg} / \mathrm{m}^{2}(\mathrm{~d} 1) \\
\text { G: } 1000 \mathrm{mg} / \mathrm{m}^{2}(\mathrm{~d} 1,8) \\
\text { q3wk }\end{array}$ & 21.6 & 53.6 & 20.5 & 28.8 & $14.4(G 3)$ \\
\hline $\begin{array}{l}\text { Skarlos } \\
\text { (2005) }\end{array}$ & 37 & $\begin{array}{l}\text { P: } 25 \mathrm{mg} / \mathrm{m}^{2}(\mathrm{~d} 1) \\
\text { G: } 650 \mathrm{mg} / \mathrm{m}^{2}(\mathrm{~d} 1,8) \\
\text { q4wk }\end{array}$ & 22.0 & 27.5 & $2.7^{*}$ & 18.9 & $5.4(\mathrm{G} 2 / 3)$ \\
\hline $\begin{array}{l}\text { Petru } \\
(\mathbf{2 0 0 6 )}\end{array}$ & 31 & $\begin{array}{l}\text { P: } 30 \mathrm{mg} / \mathrm{m}^{2}(\mathrm{~d} 1) \\
\text { G: } 650 \mathrm{mg} / \mathrm{m}^{2}(\mathrm{~d} 1,8) \\
\text { q4wks }\end{array}$ & 33.0 & 46.7 & $3.0^{* *}$ & 26.0 & $16.0(G 2 / 3)$ \\
\hline
\end{tabular}

* time to failure (month)

** month

Pl-resist: platinum resistant or refractory

RR: response rate, G: grade, neutro: neutropenia

JJC 2003;89: 1180-1184

PPE: palmar-plantar erythrodysesthesia

Table 2. Phase II studies of PLD + GEM inpatients with platinum-resistant disease.

\begin{tabular}{|c|c|c|c|c|c|c|c|c|}
\hline \multirow{3}{*}{$\begin{array}{l}\begin{array}{l}\text { Author } \\
\text { (year) }\end{array} \\
\begin{array}{l}\text { Verhar- } \\
\text { Langeris }{ }^{1} \\
(2006)\end{array}\end{array}$} & \multirow{2}{*}{\multicolumn{2}{|c|}{ No. of pts }} & \multirow{2}{*}{$\begin{array}{l}\text { Dose/ } \\
\text { Schedule }\end{array}$} & \multirow{3}{*}{$\begin{array}{c}\text { RR(\%) } \\
28.0 *\end{array}$} & \multirow{3}{*}{$\begin{array}{l}\begin{array}{l}\text { Clinical } \\
\text { benefit(\%) }\end{array} \\
72.0^{*}\end{array}$} & \multirow{3}{*}{$\begin{array}{l}\begin{array}{l}\text { Response } \\
\text { duration (wk) }\end{array} \\
\text { NR }\end{array}$} & \multicolumn{2}{|c|}{ Toxicity(\%) } \\
\hline & & & & & & & \multicolumn{2}{|c|}{ G3/4neutro } \\
\hline & $27 *$ & & $\begin{array}{l}30 \mathrm{mg} / \mathrm{m}^{2}(\mathrm{~d} 1) \\
1 \mathrm{mg} / \mathrm{m}^{2} / \mathrm{d}(\mathrm{d} 1-5) \\
\mathbf{w k}\end{array}$ & & & & 70.4 & 3.7 (G3) \\
\hline $\begin{array}{l}\text { Katsaros }{ }^{2} \\
\text { (2005) }\end{array}$ & 32 & $\begin{array}{l}\text { P: } \\
\text { V: } \\
q 3\end{array}$ & $\begin{array}{l}30 \mathrm{mg} / \mathrm{m} 2(\mathrm{~d} 1) \\
30 \mathrm{mg} / \mathrm{m} 2(\mathrm{~d} 1) \\
\text { Nk }\end{array}$ & 43.3 & 70.0 & NR & 12.5 & $6.3(\mathrm{G} 3 / 4)$ \\
\hline $\begin{array}{l}\text { Nicoletto } \\
\text { (2005) }\end{array}$ & 43 & $\begin{array}{l}\text { P: } \\
\text { O: } \\
q 4\end{array}$ & $\begin{array}{l}30-35 \mathrm{mg} / \mathrm{m}^{2}(\mathrm{~d} 1) \\
70 \mathrm{mg} / \mathrm{m}^{2}(\mathrm{~d} 1) \\
\text { wk }\end{array}$ & $\begin{array}{l}66.7^{* *} \\
\left(28.6^{*}\right)\end{array}$ & $\begin{array}{c}82.8^{* *} \\
\left(71.4^{*}\right)\end{array}$ & NR & 9.3 & $4.7(G 2)$ \\
\hline $\begin{array}{l}\text { Recchia }^{4} \\
\text { (2007) }\end{array}$ & 40 & $\begin{array}{l}\text { P: } 4 \\
\text { O: } \\
\text { q3 }\end{array}$ & $\begin{array}{l}0 \mathrm{mg} / \mathrm{m}^{2} \text { over } 2 \text { days } \\
120 \mathrm{mg} / \mathrm{m}^{2} \text { over } 2 \text { days } \\
\text { wks }\end{array}$ & $\begin{array}{l}81.5^{* *} \\
\left(38.5^{*}\right)\end{array}$ & $\begin{array}{l}100 * * \\
(76.9 *)\end{array}$ & NR & 37.5 & $10.0(G 2)$ \\
\hline
\end{tabular}

\footnotetext{
*patients with platinum-resistant

** patients with platinum-sensitive

$\mathrm{T}$ : topotecan, V: vinorelbine, O: oxaliplatin,

$\mathrm{RR}$ : response rate, G: grade, neutro: neutropenia

PPE: palmar-plantar erythrodysesthesia
}

$$
\begin{aligned}
& \text { Int J Gynecol Cancer 2006;16:65-70 } \\
& \text { Ann Oncol 2005;16:300-306 } \\
& \text { Gynecol Oncol 2006;100:318-323 }
\end{aligned}
$$

Table 3. Phase II studies of PLD-combination in platinum- and taxane-pretreated patients.

\section{Irinotecan}

Irinotecan has achieved a response rate of $23.6 \%$ in recurrent ovarian cancer. 28) Irinotecan/cisplatin combination chemotherapy has shown a response rate of $33 \%$ in platinum-resistant ovarian cancer, ${ }^{29)}$ and $76 \%$ when used as the initial regimen for epithelial 
ovarian cancer. ${ }^{30)}$ Regarding dose-limiting toxicity, although neutropenia and diarrhea were observed, diarrhea was thought to cause no remarkable problems in the combination regimen examined. Based on these results, irinitecan is considered to be useful drug in chemotherapy for ovarian cancer. There were two phase II studies of single agent of irinotecan for platinum- and taxane-resistant ovarian cancer. Matsumoto et al. treated 28 patients with platinum- and taxane-resistant or refractory ovarian cancer with irinotecan (irinotecan $100 \mathrm{mg} / \mathrm{m} 2$, days $1,8,15$, every 4 weeks), and they observed a response rate of $28.5 \%$ with a SD rate of $32.1 \%$, and the clinical benefit was obtained in $60.7 \%$ of the patients.

31) Grade 3 or 4 neutropenia and diarrhea were shown in $17.9 \%$ and $10.7 \%$ of the patients, respectively. They concluded that the weekly dosing schedule of irinotecan seems to be effective and safe salvage chemotherapy regimen for platinum- and taxane-resisitant or refractory epithelial ovarian cancer. There are few studies of irinotecan, commonly used in Japan for second-line chemotherapy, from Europe and the United States. Bodurka et al. conducted a clinical trial of irinotecan at a dose of $300 \mathrm{mg} / \mathrm{m}^{2}$ every 3 weeks in 31 platinumresistant and platinum-refractory patients. ${ }^{32}$ ) The response rate was $17 \%$ and lower than that Matsumoto et al. reported; however, irinotecan had at least an equivalent effect to topotecan and GEM. Furthermore, 14 (48\%) patients had stable disease (SD) and 65\% showed a clinical benefit, which was similar to the result of Matsumoto et al. There are no data directly comparing irinotecan and topotecan, which have similar active mechanism; however, in a comparison between the results of a phase II study in Japanese patients with recurrent ovarian cancer (topotecan: $1.2 \mathrm{mg} / \mathrm{m}^{2}$, days 1-5, every 3 weeks), 33) the results of Matsumoto et al. (irinotecan: $100 \mathrm{mg} / \mathrm{m}^{2}$, days 1, 8 and 15, every 4 weeks), 31 ) and the results of Bodurka et al. (irinotecan: $300 \mathrm{mg} / \mathrm{m}^{2}$, every 3 weeks), ${ }^{32}$ ) toxicities markedly differed. The incidences of hematotoxicity of grade 3 or more were higher in the topotecan group; i.e., the incidence of neutropenia of grade 3 or more was $95.8 \%$ in the topotecan group, but $17.9 \%$ and $35.5 \%$ in the irinotecan groups of Matsumoto et al. and Bodurka et al., respectively. Furthermore, thrombopenia occurred in $97 \%$ of the topotecan group, but rarely in the irinotecan groups ( $0 \%$ and $6.5 \%$ in studies of Matsumoto et al. and Bodurka et al., respectively). Diarrhea frequently occurred in the irinotecan groups with $\geq$ grade 3 incidences of $10.7 \%$ and $32.3 \%$ in Matsumoto et al. and Bodurka et al., respectively. On the other hand, the incidence in the topotecan group was low $(7.1 \%)$. As shown above, in treatment with topotecan and irinotecan for patients with recurrent ovarian cancer, hematotoxicity and diarrhea should be monitored, respectively.

\subsection{Combination with cisplatin}

The synergism between irinotecan and cisplatin, 34) the different mechanism of action between the two drugs, ${ }^{35)}$ some lack of cross-resistance, ${ }^{36)}$ and the relative absence of overlapping principal toxicities support the rationale behind considering combination therapy with these agents. Minagwa et al. reported that in cisplatin-resistant Hela cells cisplatin showed a collateral sensitivity to SN-38, an active metabolite of irinotecan. ${ }^{37}$ ) Furthermore, isobologram analysis indicated synergistic interaction of cisplatin and SN-38 for cisplatin-resistant Hela cells. Based on the results of a phase I study, our group conducted a phase II study with irinotecan and cisplatin. ${ }^{29)}$ Twenty-five patients with recurrent ovarian cancer who had previously undergone platinum-based combination chemotherapy received this treatment consisting of 50 or $60 \mathrm{mg} / \mathrm{m} 2$ of irinotecan on days 1 , 8 , and 15 , and 50 or $60 \mathrm{mg} / \mathrm{m} 2$ of cisplatin on day1 every 4 weeks administrated 
intravenously. The overall response rate was $40 \%$. Even when the analysis was limited to 21 platinum-resistant cases, the response rate was $33.3 \%$ with a stable disease (SD) rate of $38.1 \%$, and the clinical benefit was obtained in 15/21 (71.4\%) patients (Table 4). Neutropenia occurred in $54.5 \%$ of cycles and $64 \%$ of patients. Although diarrhea was observed in $31.8 \%$ of the courses, there were only a few severe cases $(3.0 \%)$, and this condition could be managed with the administration of loperamide and/or Kanpo medicine along with adequate hydration. Irinotecan/cisplatin represented a useful doublet regimen for platinum-resistant disease because high clinical benefit was shown, and irinotecan may induce relatively mild hematologic toxicity, particularly, thrombocytopenia, compared with topotecan. Neutropenia was reserved by short-term G-CSF. Although diarrhea frequently occurs during irinitecan monotherapy, it is no longer thought to be a serious toxicity in combination chemotherapy due to irinotecan dose reduction.

\begin{tabular}{|c|c|c|c|c|c|c|c|}
\hline \multirow{2}{*}{$\begin{array}{l}\text { Author } \\
\text { Irinotecan/ } \\
\text { Cisplatin }\end{array}$} & No. of pts & \multirow[t]{2}{*}{ Dose/ Schedule } & \multirow[t]{2}{*}{$\operatorname{RR}(\%)$} & \multirow{2}{*}{$\begin{array}{l}\text { Clinical } \\
\text { Benefit (mo) }\end{array}$} & \multirow{2}{*}{$\begin{array}{l}\text { Time to } \\
\text { Progression (mo) }\end{array}$} & \multicolumn{2}{|c|}{ G3/4Toxicity(\%)/per patient } \\
\hline & & & & & & Neutropenia & Diarrhea \\
\hline $\begin{array}{l}\text { Sugiyama } \\
\text { (1998) }\end{array}$ & 21 & $\begin{array}{l}\text { P: } 50 \text { or } 60 \mathrm{mg} / \mathrm{m}^{2}(\mathrm{~d} 1) \\
\text { I: } 50 \text { or } 60 \mathrm{mg} / \mathrm{m}^{2}(\mathrm{~d} 1,8,15) \\
\mathrm{q} 4 \mathrm{wk}\end{array}$ & 33.3 & 71.4 & 6.0 & 64.0 & 4.0 \\
\hline \multicolumn{8}{|c|}{$\begin{array}{l}\text { Irinotecan/ } \\
\text { Oral etoposide }\end{array}$} \\
\hline $\begin{array}{l}\text { Nishio } \\
\text { (2007) }\end{array}$ & 27 & $\begin{array}{l}\text { I: } 70 \mathrm{mg} / \mathrm{m}^{2}(\mathrm{~d} 1,15) \\
\text { E: } 50 \mathrm{mg} / \mathrm{day}(\mathrm{d} 1-21) \\
\text { q4wk }\end{array}$ & 44.4 & 85.1 & 9.0 & 59.3 & 7.4 \\
\hline $\begin{array}{l}\text { Shoji } \\
(2010))\end{array}$ & 31 & $\begin{array}{l}\text { I: } 70 \mathrm{mg} / \mathrm{m}^{2}(\mathrm{~d} 1,8) \\
\text { E: } 50 \mathrm{mg} / \mathrm{day}(\mathrm{d} 1-21) \\
\text { q4wk }\end{array}$ & 41.9 & 77.4 & $\begin{array}{l}7.0 \\
\text { (SD 11.0) }\end{array}$ & 52.4 & 4.8 \\
\hline $\begin{array}{l}* \text { month } \\
\text { SD: stable dise }\end{array}$ & & & & & $\begin{array}{l}1 . \\
2 . \\
3 .\end{array}$ & $\begin{array}{l}\text { Cancer Lett } \\
\text { Gynecol Onc } \\
\text { Int I Gynecol }\end{array}$ & $\begin{array}{l}\text { 98;128: 211-218 } \\
\text { 2007;106: 342-347 } \\
\text { ancer 2010 }\end{array}$ \\
\hline
\end{tabular}

Table 4. Phase II studies of irinotecan-combinations in patients with platinum-resistant disease.

\subsection{Combination with oral etoposide}

Etoposide, a topoisomerase-II inhibitor, has high antitumor activity against various animal and human malignancies. The efficacy of etoposide may be regimen-dependent, since prolonged oral administration has yielded better results than intravenous administration. The largest study to date, performed by the Gynecologic Oncology Group (GOG), reported a response rate of $8.3 \%{ }^{38}$ ) Rose et al. gave oral etoposide $(50 \mathrm{mg} / \mathrm{kg}$ of body weight) from days 1 to 21 every 4 weeks to 41 patients with platinum-resistant or 25 patients with platinum/taxane-resistant ovarian cancer and obtained response rates of $26.8 \%$ and $32 \%$, respectively. ${ }^{39)}$

DNA topoisomerase-I and -II are nuclear enzymes that participate in various genetic processes, including transcription, replication, recombination and chromosome segregation 
at mitosis. ${ }^{40)}$ These two DNA topoisomerases are functionally related and act in concert. Both seem to be essential for maintaining cell viability throughout the cell cycle. Topoisomerase-I treatment induces an increase in the S-phase cell population with an increase in topoisomerase-II mRNA expression. Thus, topoisomerase-I can modulate topoisomerase-II levels to enhance the effect of topoisomerase-II inhibitors. ${ }^{41,42)}$ Therefore, combined use of topoisomerase-I and-II targeting agents could theoretically inhibit both DNA and RNA synthesis completely, resulting in synergistic cytotoxicity.

We undertook a pilot study and a phase II study to evaluate the antitumor efficacy and toxicity of a combination of irinotecan and oral etoposide in women with platinum- and taxane-resistant ovarian cancer. ${ }^{43,44)}$ In both studies, irinotecan was administered in an intravenous dose of 60 or $70 \mathrm{mg} / \mathrm{m}^{2}$ as a 90 -min infusion on days 1 and 15 of a 28-day cycle, and etoposide was administered in an oral dose of $50 \mathrm{mg} /$ body on days 1 to 21 . The two studies showed very similar results for efficacy (according to the RECIST and CA125 criteria) and toxicity (Table 4). A pilot study of irinotecan and oral etoposide in platinumand taxane-resistant ovarian cancer reported an overall response rate of $44.4 \%$ in 12/27cases, and the median duration of response was 11 months. ${ }^{43)}$ Adding 11 patients with SD, a high clinical benefit was shown in $23 / 27$ cases $(85.1 \%)$. The median time to progression and the median survival in the study group as a whole was 9 months and 17 months, respectively. The major toxicity was neutropenia (grade 3/4,59\%), but was managed easily by administration of short-term G-CSF. Febrile neutropenia was observed in only one patient. Diarrhea was infrequent and mild. The other study was conducted in the northern area of Japan (Tohoku Gynecologic Cancer Unit). ${ }^{44)}$ Forty-two patients with recurrent epithelial ovarian cancer who had previously undergone platinum-based combination chemotherapy were registered in this study, and the overall response rate was $50.0 \%$. Even when the analysis was limited to 31 platinum-resistant cases, a response rate of $41.9 \%$ and clinical benefit of $77.4 \%$ were achieved. As for toxicity, grade $3 / 4$ neutropenia was observed in 22 patients $(52.4 \%)$ and febrile neutropenia in 3 patients (7.1\%). Grade 3/4 diarrhea occurred in only two patients (4.8\%). Acute myeloid leukemia (AML) developed as a secondary malignancy in one patient in each study. Topoisomerase-II-related AML, initially noted as a therapy-related complication of childhood leukemia, is characterized by the lack of a myelodysplastic phase, no dysplastic change in diagnostic bone marrow specimens, balanced chromosomal translocations involving 11q23, and variable chemosensitivity. This leukemia is characteristically related to the cumulative dose of etoposide and has a shorter latency period (median, 24 to 30 months) than the AML associated with alkylating agent therapy. In general, a total dose of etoposide of more than $6 \mathrm{~g}$ may be associated with an increased risk of developing leukemia. The total dose of etoposide received by the two patients who had AML in the two studies was $10.5 \mathrm{~g}$ and $14.2 \mathrm{~g}$, respectively. We strongly recommended that this regimen not be given for more than 6 cycles, even if the response or stable disease is sustained. These results of the two studies justify further studies of irinotecan plus oral etoposide in patients with platinum- and taxane-resistant epithelial ovarian cancer.

\section{Conclusions}

In the treatment of platinum- and taxane- resistant recurrent ovarian cancer, monotherapy is recommended from the perspective of toxicity. However, monotherapy of PLD and irinotecan, which have specific non-hematotoxicities, increases the incidence and severity of 
HFS, stomatitis and diarrhea, resulting in a decreased patient QOL. We investigated whether combination therapy of these drugs with other drugs would exploit their advantages at lower doses. The results of studies of combination therapy of PLD or irinotecan showed lower incidences of the non-hematotoxicities specific to these drugs at the same time good patient QOL was maintained; furthermore, a good clinical benefit was shown without loss of the effect in comparison with that of monotherapy. In conclusion, we propose the use of combination therapy using PLD or irinotecan in the treatment of platinum- and taxane- resistant recurrent ovarian cancer.

\section{Summary}

In the treatment of platinum- and taxane-resistant recurrent cancer, monotherapy is recommended as the standard treatment from the perspective of toxicity. However, pegylated liposomal doxorubicin (PLD) and irinotecan have specific non-hematotoxicities that impair the quality of life (QOL) of patients; therefore, combination therapy at lower doses may provide better clinical benefit than monotherapy, especially as it can be maintained for a longer time because the lowering of the doses decreases the specific toxicities.

\section{References}

[1] Blackledge G, Lawton F, Redman C, et al. Response of patients in phase II studies of chemotherapy in ovarian cancer: Implications for patients treatment and the design of phase II trilas. Br J Cancer 1989;59: 650-3

[2] Markman M, Reichman B, Hakes T, et al. Response to second-line cisplatin-based intraperitoneal therapy in ovarian cancer: Influence of a prior response to intravenous cisplatin. J Clin Oncol 1991;9:1801-5

[3] Sugiyama T and Kumagai S. Pegylated liposomal doxorubicin for advanced ovarian cancer in women who are refractory to both platinum- and paclitaxel-based chemotherapy regimens. Clinical Medicine: Therapeutics 2009;1:1227-1236.

[4] Cesano A, Lane SR, Poulin R, Ross G, Fields S. Stabilization of disease as a useful predictor of survival following second-line chemotherapy in small cell lung cancer and ovarian cancer. Int J Oncol 1999;15: 1233-1238.

[5] Rose P, Tian C, Bookman MA. Assessment of tumor response as a surrogate endpoint of survival in recurrent/platinum-resistant ovarian carcinoma: a Gynecologic Oncology Group study. Gynecol Oncol 2010;117: 324-329.

[6] Ando Y, Saka H, Ando M, et al. Polymorphisms of UDP-glucuronosyltransferase I in Gilbert's syndrome. Cancer Res 2000;60: 6921-6926.

[7] Takano M, Kato M, Yoshikawa $T$, et al. Clinical significance of UDPglucuronosyltransferase $1 \mathrm{~A} 1 * 6$ for toxicities of combination chemotherapy with irinotecan and cisplatin in gynecologic cancers. Oncology 2009;76: 315-321.

[8] Muggia FM, Hainsworth JD, Jeffers S, Miller P, Groshen S, Tan M, Roman L, Uziely B, Muderspach L, Garcia A, Burnett A, Greco FA, Morrow CP, Paradiso LJ, Liang Li-J. Phase II study of liposomal doxorubicin in refractory ovarian cancer: antitumor activity and toxicity modification by liposomal encapsulation. J Clin Oncol 1997;15: 987-993. 
[9] Gordon AN, Granai CO, Rose PG, Hainsworth J, Lopez A, Weissman C, Rosales R, Sharpington T. Phase II study of liposomal doxorubicin in platinum- and paclitaxel-refractory epithelial ovarian cancer. J Clin Oncol 2000;18:3093-3100.

[10] Markman M, Kennedy A, Webster K, Peterson G, Kulp B, Belinson J. Phase 2 trial of liposomal doxorubicin $(40 \mathrm{mg} / \mathrm{m} 2)$ in platinum/paclitaxel-refractory ovarian and fallopian tube cancers and primary carcinoma of the peritoneum. Gynecol Oncol 2000;78: 369-372.

[11] Wilailak S, Linasmita V. A study of pegylated liposomal doxorubicin in platinumrefractory epithelial ovarian cancer. Oncology 2004;67: 183-186.

[12] Chou HH, Wang KL, Chen CA, Wei LH, Lai CH, Hsieh CY, Yang YC, Twu NF, Chang TC, Yen MS. Pegylated liposomal doxorubicin (Lipo-Dox) for platinum-resistant or refractory epithelila ovarian carcinoma: a Taiwanese gynecologic oncology group study with long-term follow-up. Gynecol Oncol 2006;101: 423-428.

[13] Gordon AN, Fleagle JT, Guthrie D, Parkin DE, Gore ME, Lacave AJ. Recurrent epithelial ovarian carcinoma: a randomized phase III study of pegylated liposomal doxorubicin versus topotecan. J Clin Oncol 2001;19: 3312-3322.

[14] Mutch DG, Orlando M, Goss T, Teneriello MG, Gordon AN, McMeekin SD, Wang Y, Scribner Jr DR, Marciniack M, Naumann RW, Secord AA. Randomized phase III trial of gemcitabine compared with pegylated liposomal doxorubicin in patients with platinum-resistant ovarian cancer. J Clin Oncol 2007;25: 2811-2818.

[15] Ferrandina G, Ludovisi M, Lorusso D, Pignata S, Breda E, Savarese A, Del Medico P, Scaltriti L, Katsaros D, Priolo D, Scambia G. Phase III trial of gemcitabine compared with pegylated liposomal doxorubicin in progressive or recurrent ovarian cancer. J Clin Oncol 2008;26: 890-896.

[16] Katsumata N, Fujiwara Y, Kamura T, Nakanishi T, Hatae M, Aoki D, Tanaka K, Tsuda H, Kamiura S, Takehara K, Sugiyama T, Kigawa J, Fujiwara K, Ochiai K, Ishida R, Inagaki M, Noda K. Phase II clinical trial of pegylated liposomal doxorubicin (JNS002) in Japanese patients with mullerian carcinoma (epithelial ovarian carcinoma, primary carcinoma of fallopian tube, peritoneal carcinoma) having a therapeutic history of platinum-based chemotherapy: a phase II study of the Japanese Gynecologic Oncology Group. Jpn J Clin Oncol 2008;38: 777-785.

[17] Ten Bokkel Huinink W, Gore M, Carmichael J, et al. Topotecan versus paclitaxel for the treatment of recurrent epithelial ovarian cancer. J Clin Oncol 1997;15: 2183-2193.

[18] Gordon AN, Tonda M, Sun S, Rackoff W, on behalf of the Doxil Study 30-49 investigators.Long-term survival advantage for women treated with pegylated liposomal doxorubicin compared with topotecan in a phase 3 randomized study of recurrent and refractory epithelial ovarian cancer. Gynecol Oncol 2004;95: 1-8.

[19] Chow KU, Ries J, Weidmann E, Pourebrahim F, Napieralski S, Stieler M, Boehrer S, Rummel MJ, Stein J, Hoelzer D, Mitrou PS. Induction of apoptosis using $2^{\prime}, 2^{\prime}$ difluorodeoxycytidine (gemcitabine) in combination with antimetabolites or anthracyclines on malignant lymphatic and myeloid cells. Antagonism or synergism depends on incubation schedule and origin of neoplastic cells. Ann Hematol 2000;79: 485-492.

[20] D'Agostino G, Ferrandia G, Ludovisi M, Testa A, Lorusso D, Gbaguidi N, Breda E, Mancuso S, Scambia G. Phase II study of liposomal doxorubicin and gemcitabine in the salvage treatment of ovarian cancer. Br J Cancer 2003;89: 1180-1184. 
[21] Ferrandina G, Paris I, Ludovisi M, D'Agostino G, Testa A, Lorusso D, Zanghi M, Pisconti S, Pezzella G, Adamo V, Breda E, Scambia G. Gemcitabine and liposomal doxorubicin in the salvage treatment of ovarian cancer: updated results and longterm survival. Gynecol Oncol 2005;98: 267-273.

[22] Skarlos DV, Kalofonos HP, Fountzilas G, Dimopoulos MA, Pavlidis N, Razis E, Economopoulos T, Pectasides D, Gogas H, Kosmidis P, Bafaloukos D, Klouvas G, Kyratzis G, Aravantinos G. Gemcitabine plus pegylated liposomal doxorubicin in patients with advanced epithelial ovarian cancer resistant/refractory to platinum and/or taxanes. A HeCOG phase II study. Anticancer Res 2005; 25: 3103-3108.

[23] Petru E, Angleitner-Boubenizek L, Reinthaller A, Deibl M, Zeimet AG, Volgger B, Stempfl A, Marth C. Combined PEG liposomal doxorubicin and gemcitabine are active and have acceptable toxicity in patients with platinum-refractory and resistant ovarian cancer after previous platinum-taxane therapy: a phase II Austrian AGO study. Gynecol Oncol 2006;102: 226-229.

[24] Jonsson E, Friborg H, Nygren P, Larsson R. Synergistic interactions of combinations of topotecan with standard drugs in primary cultures of human tumor cells from patients. Eur J Clin Pharmacol 1998;54: 509-514.

[25] Verhaar-Langereis M, Karakus A, van Eijkeren M, Voest E, Witteveen E. Phase II study of the combination of pegylated liposomal doxorubicin and topotecan in platinumresistant ovarian cancer. Int J Gynecol Cancer 2006;16: 65-70.

[26] Nicoletto MO, Falci C, Pianalto D, Artioli G, Azzoni P, De Masi G, Ferrazzi E, Perin A, Donach M, Zoli W. Phase II study of pegylated liposomal doxorubicin and oxaliplatin in relapsed advanced ovarian cancer. Gynecol Oncol 2006;100: 318-323.

[27] Recchia F, Saggio G, Amiconi G, Di Blasio A, Cesta A, Candeloro G, Carta G, Necozione S, Mantovani G, Rea S. A multicenter phase II study of pegylated liposomal doxorubicin and oxaliplatin in recurrent ovarian cancer. Gynecol Oncol 2007;106: 164-169.

[28] Takeuchi S, Dobashi K, Fujimoto S, et al. A late phase II study of CPT-11 on uterine cervical cancer and ovarian cancer. Research Groups of CPT-11 in Gynecologic Cancers. Jpn J Cancer Chemother 1991;18: 1861-1869.

[29] Sugiyama T, Yakushiji M, Nishida T, et al. Irinotecan (CPT-11) combined with cisplatin in patients with refractory or recurrent ovarian cancer. Cancer Lett 1998;128: 211218.

[30] Sugiyama T, Yakushiji M, Kamura T, et al. Irinotecan (CPT-11) and cisplatin as first-line chemotherapy for advanced ovarian cancer. Oncology 2002;63: 16-22.

[31] Matsumoto K, Katsumata N, Yamanaka Y, Yonemori K, Kohno T, Shimizu C, et al. The safety and efficacy the weekly dosing of irinotecan for platinum and taxanesresistant ovarian cancer. Gynecol Oncol 2006;100: 412-416.

[32] Bodurka DC, Levenback C, Wolf JK Gano J, Wharton JT, Kavanagh JJ, et al. Phase II trial of irinotecan in patients with metastatic epithelial ovarian or peritoneal cancer. J Clin Oncol 2003;21: 291-297.

[33] Aoki D, Katsumata N, Nakanishi T, et al. A phase II clinical trial of topotecan in Japanese patients with relapsed ovarian carcinoma. Jpn J Clin Oncol 2010;

[34] Kudoh S, Takada M, Masuda N, et al. Enhanced anti-tumor efficacy of a combination of CPT-11, a new derivative of camptothecin, and cisplatin against lung tumor xenografts. Jpn J Cancer Res 1993;84: 203-207. 
[35] Kunimoto T, Nitta K, Tanaka T, et al. Antitumor activity of 7-ethyl-10-[4-(1-piperidino)1-piperidino]carbonyloxy-camptothecin, a novel water-soluble derivative of camptothecin, against murine tumors. Cancer Res 1987;47: 5944-5947.

[36] Tsuruo T, Matsuzaki T, Matsushita M et al. Antitimor effect of CPT-11, a new derivative of camptothecin, against pleiotropic drug-resistant tumors in vitro and in vivo. Cancer Chemother Pharmacol 1988;21: 71-74.

[37] Minagawa $Y$, Kigawa J, Ishihara H, Itamochi H, Terakawa N. Synergistic enhancement of cisplatin cytotoxicity by SN-38, an active metabolite of CPT-11, for cisplatinresistant HeLa cells. Jpn J Cancer Res. 1994; 85: 966-971.

[38] Slayton RE, Creasman WT, Petty W, et al. Phase II trial of VP-16-213 in the treatment of advanced squamous cell carcinoma of the cervix and adenocarcinoma of the ovary. A Gynecologic Oncology Group study. Cancer Treat Rep 1979;63: 2089-2092.

[39] Rose PG, Blessing JA, Mayer AR, Homesley HD. Prolonged oral etoposide as secondline therapy for platinum-resistant and platinum-sensituve ovarian carcinoma: a Gynecologic Oncology Group study. J Clin Oncol 1998;16: 405-410.

[40] Wang JC. DNA topoisomerases. Annu Rev Biochem 1985;54: 665-697.

[41] Kim R, Hirabayashi N, Nishiyama M, et al. Experimental studies on biochemical modulation targeting topoisomerase I and II in human tumor xenografts in nude mice. Int J Cancer 1992;50: 760-766.

[42] Masumoto N, Nakano S, Esaki T, et al. Sequence-dependent modulation of anticancer drug activities by 7-ethyl-10-hydroxycamptothecin in an HST-1 human squamous carcinoma cell line. Anticancer Res 1995;14: 405-409.

[43] Nishio S, Sugiyama T, Souji T, et al. Pilot study evaluationg the efficacy and toxicity of irinotecan plus oral etoposide for platinum- and taxane-resistant epithelial ovarian cancer. Gynecol Oncol 2007;106: 342-347.

[44] Shoji T, Takatori E, Omi H, et al. Phase II clinical study of the combination chemotherapy regimen of irinotacan plus oral etoposide for the treatment of recurrent ovarian cancer (Tohoku Gynecologic Cancer Unit 101 Group study). Int J Gynecol Cancer 2010;21:44-50. 


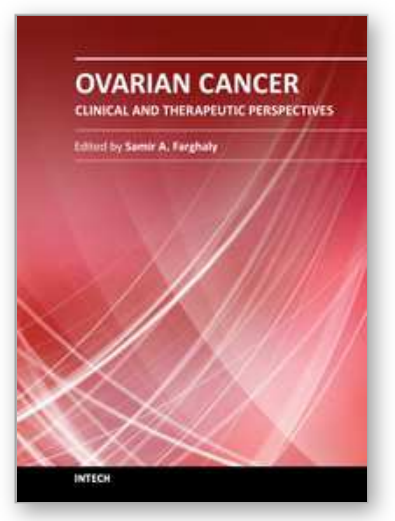

\author{
Ovarian Cancer - Clinical and Therapeutic Perspectives \\ Edited by Dr. Samir Farghaly
}

ISBN 978-953-307-810-6

Hard cover, 338 pages

Publisher InTech

Published online 15, February, 2012

Published in print edition February, 2012

Worldwide, Ovarian carcinoma continues to be responsible for more deaths than all other gynecologic malignancies combined. International leaders in the field address the critical biologic and basic science issues relevant to the disease. The book details the molecular biological aspects of ovarian cancer. It provides molecular biology techniques of understanding this cancer. The techniques are designed to determine tumor genetics, expression, and protein function, and to elucidate the genetic mechanisms by which gene and immunotherapies may be perfected. It provides an analysis of current research into aspects of malignant transformation, growth control, and metastasis. A comprehensive spectrum of topics is covered providing up to date information on scientific discoveries and management considerations.

\title{
How to reference
}

In order to correctly reference this scholarly work, feel free to copy and paste the following:

Toru Sugiyama (2012). Second-Line Chemotherapy for Platinum- and Taxane-Resistant Epithelial Ovarian Cancer: Pegylated Liposomal Doxorubicin (PLD), Irinotecan, and Combination Therapies at Lower Doses, Ovarian Cancer - Clinical and Therapeutic Perspectives, Dr. Samir Farghaly (Ed.), ISBN: 978-953-307-810-6, InTech, Available from: http://www.intechopen.com/books/ovarian-cancer-clinical-and-therapeuticperspectives/second-line-combination-therapy-for-platinum-and-taxane-resistant-epithelial-ovarian-cancer

\section{INTECH}

open science | open minds

\author{
InTech Europe \\ University Campus STeP Ri \\ Slavka Krautzeka 83/A \\ 51000 Rijeka, Croatia \\ Phone: +385 (51) 770447 \\ Fax: +385 (51) 686166 \\ www.intechopen.com
}

\author{
InTech China \\ Unit 405, Office Block, Hotel Equatorial Shanghai \\ No.65, Yan An Road (West), Shanghai, 200040, China \\ 中国上海市延安西路65号上海国际贵都大饭店办公楼 405 单元 \\ Phone: +86-21-62489820 \\ Fax: +86-21-62489821
}


(C) 2012 The Author(s). Licensee IntechOpen. This is an open access article distributed under the terms of the Creative Commons Attribution 3.0 License, which permits unrestricted use, distribution, and reproduction in any medium, provided the original work is properly cited. 